\title{
Leadership Based on the Internal Quality Assurance System in the Christian University of Indonesia
}

\author{
Hotmaulina Sihotang \\ Program Pascasarjana \\ Universitas Kristen Indonesia \\ Cawang, Jakarta Timur \\ hotmaulina.sihotang@uki.ac.id
}

\author{
Bernadetha Nadeak \\ Fakultas Kedokteran \\ Universitas Kristen Indonesia \\ Cawang, Jakarta Timur \\ bernadetha.nadeak@uki.ac.id
}

\begin{abstract}
Abstrac-This study aims to determine the readiness of faculty and postgraduate program and to find a leadership model to implement the internal quality assurance (IQA) system consistently and sustainably. The method of the research was qualitative and quantitative approach. The data were obtained through interview result, internal quality audit result and questionnaire, and the sample was 168 permanent lecturers. The data analysis is done by organizing, synthesizing the data, and making conclusions. The findings of this research are as follows: Faculty and postgraduate program (1) have set 31 standard of quality, (2) have implemented 31 quality standard but still less understood, (3) have already done the audit and respond positively to internal quality audit activities, (4) audit results have been submitted to the rector of the university, (5) some leaders accept but some are resistant to the development of standards to 62 quality standards in faculty level. Furthermore, from the data found that the leadership style which supports the implementation of IQA system is the implementation of the task, so it can be concluded that the leadership style of the implementation tasks is recommended in the implementation of IQA system in universities.
\end{abstract}

Keywords—Leadership, implementation and IQA system

\section{INTRODUCTION}

Since its first launch in 2003 by the Directorate General of Higher Education, quality assurance activities at universities have now been underway for thirteen years. Within that period, it has evolved various variations of implementation of quality assurance at university level. Since the launching of quality assurance activities in universities, there was a principle that the Directorate General of Higher Education has inspired the quality assurance, while the implementation must be able to be done by each university in accordance with the culture, capacity, vision and mission of the universities concerned. Meanwhile, in 2006 has been completed nationally a system that synergizes EPSBED activities, quality assurance, and accreditation of universities, all of which aims to guarantee the quality of universities in Indonesia. The system is called the Higher Education Quality Assurance (HEQA) System. In HEQA System, EPSBED activities will be developed into a Higher Education
Database, while the Quality Assurance and Accreditation activities are respectively referred to as the Internal Quality Assurance (IQA) System and the External Quality Assurance (EQA) System. The process is run by universities to meet the needs and satisfaction of stakeholders internally and externally on the implementation of Tri Dharma Perguruan Tinggi. Quality assurance of higher education is an important program and must be implemented by all institutions of higher education based on the Law No. 12 of 2012 on Higher Education which mandates that the higher education should be able to establish and implement quality assurance standards.

Based on data of National Agency Board of Higher Education dated January 8, 2016 there are 11060 Study Programs at private higher education. There are $496(4.48 \%)$ study programs which accredited with A, 4235 (38,29\%) study programs which accredited B and 6329 (57,22\%) study programs which accredited with $\mathrm{C}$. The data shows that over $50 \%$ of study programs quality still have to be improved while the very good not yet up to 5\%. In Christian University of Indonesia (UKI) there are still seven (22\%) study program with $\mathrm{C}$ accreditation, twenty one $(66 \%)$ study program with B accreditation and three (10\%) study program with A accreditation out of thirty one study programs. Whereas in Renstra of UKI has been targeted that in the year 2017 UKI must become a superior university at regional level. To achieve the target as stated in Renstra UKI, the implementation of IQA system is needed to guarantee the quality of higher education.

In order to guarantee the quality of higher education can be implemented and become a culture of quality in universities, there are several prerequisites must be fulfilled so that the implementation of quality assurance can achieve the goal. The prerequisites are: commitment, paradigm shift, and mental attitude of the actors of higher education process, and organizing quality assurance in universities. Commitment is the first requirement that must exist. Commitments here include leaders, educative personnel, noneducative personnel, or support personnel. But most important is the leadership commitment, because to change the paradigm and mental attitude, and organizing a good IQA 
required leadership commitment. Without a leadership commitment all things that have been designed will not be of any use. It is clear that the role of leaders in implementing quality assurance in universities is very important. This is in line with opinion that says "leadership is a scientific management, a value displacement activity, and a trust culture"[1]. Leaders must have a vision and be able to translate that vision into IQA system policies, quality manuals, quality standards and supplemented by forms. Leadership is important because it is able to bring change, motivation, and implement IQA system in a sustainable manner. This article will discuss how the readiness of faculty leaders and postgraduate program in implementing IQA system and how the right leadership style so that can support and succeeded in delivering the institution to improve the quality consistently and continuously.

Leadership is important because it can bring change, foster motivation, and develop the competence of group members. "leaderdship is an interaction between members of a group. Leader are agent of change, person whose acts affect other people more than other people's acts affect them. Leadership occurs when one group member modifies the motivation or competencies of others in the group" [2]. Leadership as the ability to influence a group of people to achieve goals. Leadership is a process of social influence in which leaders seek voluntary participation of their subordinates in an effort to achieve organizational goals [3]. While the other opinion says that "leadership is not merely a possession of a leader, but an aspect of the community or organization. It is a communal capacity and achievement"'[4]. According to this view, leadership is a dynamic process carried out through a lead relationship between the lead and the led. The relationship takes place and develops through interpersonal transactions and mutual encouragement in the achievement of common goals. According to this view a strong leader is a leader supported by all members of his organization. While the other opinion says that "leadership is the process of influencing other to understand an agree about what needs to be done how to do it, and the process of facilitating individual and collective efforts to accomplish shared objectives"[5]. This is in line with the opinion who says that "leadership is the process of influencing and supporting others to work enthusiastically toward achieving objectives. It is the critical factor that helps an individual or a group identify it goals and then motivates and assists in achieving the stated goals. Without leadership, an organization would be only a confusion of people and machines, just as an orchestra a conductor would be only musicians and instrument,..."'6]. In line with the opinion that "leadership is developed through building interpersonal skills, social awareness, mutual respect, and trust" [7].

Each leader faces three variables: the person being led, the duties run by the people he leads, and the environment in which the person and task are located. Leadership concerning the framework of the three elements. The three elements are leaders, followers, and situations".
The three elements are interrelated, as illustrated in the figure below.

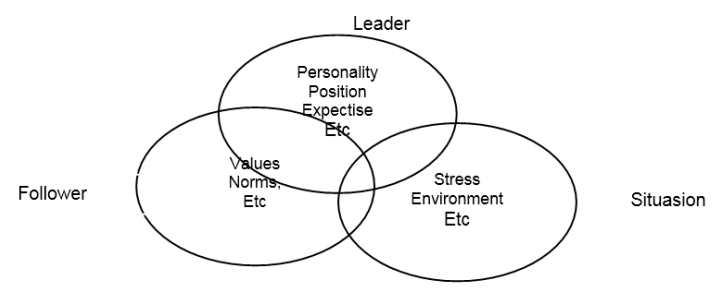

Fig 1. The relationship of leaders, followers, and situations

The influence of leaders includes: (1) The interpretation of external events by members, (2) the choice of goals and strategies to be achieved, (3) the motivation of members to achieve the goal, (4) the mutual trust and cooperation among members, (5) the working activities, (6) the development of trust and skills of members, (7) the learning and sharing of new knowledge among members, (8) Making list of support and cooperation from outsiders. In its function as a leader, leaders are expected to demonstrate three skills, namely: 1) conceptual skills, 2) human relations skills, 3) technical skills [8].

From the above concepts and theories can be concluded that leadership behavior is divided into three categories namely, 1) task-oriented with indicators: pay attention to completion of tasks, empower resources, and organize operations regularly. 2) relationship-oriented with indicators: establishing good relationships, assisting subordinates, increasing job satisfaction of subordinates, and building organizational identification. 3) Change-oriented with indicators: leads to innovation and builds commitment.

The main function of leadership can be divided in to six main function, namely: (1) instructional function, (2) consultation function, (3) participation function, (4) deligation function, (5) control function. All of these leadership functions are held in an integral leadership activity. (3) the leaders should try to develop freedom of thought and expression, (4) the leaders must develop harmonious cooperation, (5) the leaders must be able to solve problems and make decisions within the limits of their responsibilities, and (6) the leaders must use supervision as a controlling tool.

In carrying out the leadership functions, the leadership style will be visible with each pattern. "since global leaders' job functions and responsibilities are more complex and difficult than before, a future-oriented and flexible leadership style is required" [9]. Furthermore opinion says that "leadership style in an organization is one of the factors that play significant role in enhancing or retarding the interest and commitment of the individuals in the organization "'[10].

The style of leadership is the basis for classifying the type of leadership. Leadership style has three archetypes, namely: (1) Leadership style patterned on the importance of task 
implementation, (2) patterned leadership style in the implementation of cooperative relationship, and (3) leadership style which is patterned on the interests of the results achieved.

Leadership style that is patterned on the importance task implementation puts power in the hands of one person. The leader acts as the sole ruler. The positions and tasks of the subordinate are merely acts as the executor of the decisions, orders, and even the will of the leadership. Leadership style which is patterned on the interests of the results achieved, is the opposite of a leadership style patterned on the importance of task implementation, namely the leader is domiciled as a symbol. Leadership is exercised by giving full freedom to the person who is led in making decisions and performing activities according to the will and interests of each individual, as well as small group. Leaders only function themselves as advisers. Leadership style which is patterned on the implementation of cooperative relationships is a leadership style that puts people as the main and most important factor in each group/organization. Leaders view and place the people he leads as subjects who have personality with various aspects. The style of this leader is always trying to take advantage of every person he leads.

The process of ensuring the quality of higher education in a university is an independent activity of the higher education concerned. To ensure its existence is guaranteed, universities will inevitably have to run the guarantee of continuous quality of higher education (continuous improvement). In line with the opinion who said that "higher education is one of the areas that needs certain standards to assure quality"[11]. Quality assurance is the process of establishing and fulfilling the quality standards of management consistently and continuously, so that consumers, producers, and other interested parties obtain satisfaction (Ministry of National Education, 2003). While the other opinion said that "quality assurance is an organization's guarantee that the product or service it offers, meets the accepted quality standards. It is achieved by identifying what "quality" means in context; specifying methods by which its presence can be ensured; and specifying ways in which it can be measured to ensure conformance" [12]. Furthermore it is said that the quality assurance "is a multi-dimensional concept, which should embrace all its functions and activities: teaching and academic programmers, research and scholarship, staffing, students, buildings, faculties, equipment, services the community and the academic environment" [13].

Education at higher education institutions will be qualified if: (1) the university is able to establish and realize its vision through the implementation of its mission (deductive aspect); (2) the university is able to meet the needs of stakeholders (inductive aspect) in the form of: social needs (societal needs), the needs of the world of work (industrial needs). And professional needs. This opinion is supported by opinion who says that "with appropriate oversight and quality assurance, private institutions can supply these services" [14].

Specifically, the purpose of quality assurance is to maintain and improve the quality of education continuously, which is run by an internal university to realize its vision and mission, and to meet the needs of stakeholders through the implementation of Higher Education Tri Dharma. This opinion is also in line with the opinion who said that "in $a$ practical sense, quality assurance reviews provide external, third party, independent, objective insights. Such reviews offer observations about partner institutions, products, programs, services, and processes, and they provide recommendations for improvement" [15].

Achievement of quality assurance objectives through quality assurance activities which is run internally by universities shall be controlled and audited through accreditation activities carried out by $B A N-P T$ or other agencies externally. Thus, the objectivity of the assessment of the continuous maintenance and improvement of higher education quality in a university can be realized.

The university chooses and sets high quality education standards itself for each study program. The selection and stipulation of the standard is done in a number of aspects called the quality items, which are poured the quality objectives in the Renstra UKI 2015-2019.

Quality assurance of higher education in universities is run through stages that are assembled in a process as follows: 1) Higher educations set the vision and mission of higher education. 2) Based on the vision and mission of the higher education, each study program sets out the vision and mission of the study program. 3) The vision of each course is then elaborated by each study program into a set of quality standards on each item of quality as mentioned above. 4) The quality standard is formulated and defined by concocting the vision of the higher education (deductively) and the needs of stakeholders (inductively). As a standard, the formula should be specific and measurable, which contains elements ABCD (Audience, Behavior, Competence, Degree). 5) The university establishes the organization and mechanism of quality assurance work. 6) Universities undertake quality assurance by implementing PPEPP management. 7) Higher educations evaluate and revise quality standards through benchmarking on an ongoing basis.

Quality assurance of higher education can be conducted through PPEPP which will produce continuous improvement or kaizen of higher education quality in university. Some of the principles that should underlie the mindset and pattern of action of all PPEPP quality control management actors are: 1) Quality first; All thoughts and actions of higher education managers must prioritize the quality. 2) Stakeholder-in; All thoughts and actions of higher education managers should be aimed at stakeholders' satisfaction. 3) The next process is our stakeholders; Any person performing duties in the higher education process shall consider others who use the results of their duties as stakeholders to be satisfied. 4) Speak with data; Every person implementing higher education should take action and make decisions based on analysis of data that has been obtained first, not based on supposition or engineering. 5) Upstream management; All decision making 
in the higher education process is done in a participatory way.

In order to guarantee the quality of higher education, there are several prerequisites that must be fulfilled so that the implementation of quality assurance can achieve its objectives, namely: (a) commitment, (b) paradigm change, (c) mental attitude of the actors of higher education process, and (d) organizing quality assurance in universities.

\section{METHOD}

The research aims to know the readiness of faculty and postgraduate program in implementing the IQA system. In addition, to determine the style of leadership at the faculty level, and postgraduate Program that can support and deliver successfully the UKI to improve the quality consistently and sustainably.

The method used in this research was descriptive qualitative and quantitative method. Qualitative method was used to see the readiness of the leaders to implement IQA system on an ongoing basis. Quantitative method was used to find out the leadership style of the leaders. The source of the research data were deans and vice deans, directors and vice directors, heads of study programs and lecturers. In this case the subjects have a direct relationship and support the research that will be done.

The research was conducted at Christian University of Indonesia in the even semester 2015/2016. The data of leadership readiness on implementing the IQA system is obtained through observation together with an in-depth interviews and documentation which have been done by the internal quality audit. To get the data, then there are some research instruments used such as; observation sheets, interview guides, documents and questionnaires consisting of 30 statement items; before, validation on the questionnaire item was done by testing the questionnaire which consisted of 35 statement items to thirty lecturers. The result of the validation indicates that there are 5 invalid statements, so the 5 statements are dropped. A valid questionnaire distributed to the research sample consisted of only 30 statements. To know the data of leadership and implements IQA system, research population is all permanent lecturers in all faculty and postgraduate program amounted to 288 people. While the study sample was determined 168 lecturers using Slovin formula. The sampling technique as follows:

TABLE I. The Number of Lecturer from Each Faculty

\begin{tabular}{|c|c|c|c|}
\hline $\begin{array}{c}\text { Name of } \\
\text { Faculty }\end{array}$ & $\begin{array}{c}\text { Number of } \\
\text { Lecturers }\end{array}$ & Ratio & Sample \\
\hline FKIP & 44 & $15 \%$ & 26 \\
\hline FE & 27 & $9 \%$ & 16 \\
\hline FH & 17 & $6 \%$ & 10 \\
\hline FT & 34 & $12 \%$ & 20 \\
\hline FS & 12 & $4 \%$ & 7 \\
\hline
\end{tabular}

TABLE I, Cont.

\begin{tabular}{|c|c|c|c|}
\hline FISIP & 21 & $7 \%$ & 12 \\
\hline FK & 96 & $33 \%$ & 56 \\
\hline PPS & 37 & $13 \%$ & 22 \\
\hline Jumlah & $\mathbf{2 8 8}$ & $\mathbf{1 0 0 \%}$ & $\mathbf{1 6 8}$ \\
\hline
\end{tabular}

Rumus Slovin :

$\mathrm{n}=\mathrm{N} /\left(1+\mathrm{N} .(\mathrm{e})^{2}\right)$

Number of Sample (n) =

$$
\frac{288}{1+288(0,05)^{2}}=167,4418605=168
$$

A direct observation was conducted by researchers to know the matters relating to research, namely about the readiness of leaders in terms of IQA system implementation and leadership style, the approaches used and the factors that influence the leadership style played by the leader, in addition, observation technique was also useful to complete the data and information obtained through interviews, and this observation is also intended to conduct recheck or triangulation of the data. The observation used in this research is "real observation participation". Interviews are a means of rechecking or verification of information or information obtained previously. The interview techniques used by researchers in this study was in-depth interview (indepth interview).

Documentation is a data collection technique to support research, in this study, researchers used documentation tools such as: field notes and documents. Several reasons why the documentation techniques needed, namely: 1). Is a stable source of information, 2). Have strong evidentiary power, 3). Natural, and 4). Expanding the knowledge under study. This documentation is used to search for sources of information whether written, drawing or from electronic media. Data analysis is the process of searching and compiling systematically the data obtained from interviews, field notes, and other materials, so that it is easy to understand, and findings can be informed to others.

Data analysis is done by organizing data, breaking it into units, synthesizing, organizing into patterns, choosing what is important and will be learnt, and making conclusions that can be communicated to others. The analysis consists of three activities that occur simultaneously, namely: (1) data reduction; (2) Presentation of data; (3) Conclusion/verification. The examination of data validity by triangulation is a technique of examining data by utilizing something else, to compare from different angles, so as to achieve a high validity ". To check the truth of the data, in this study used three techniques triangulation, namely: source triangulation, triangulation time, triangulation techniques and member check. 
The steps in the data collection procedure in this study: (1) to approach the subject of research (informant); (2) conducting in-depth interviews to the deans, vice deans, directors and vice directors and to know the implementation of the leadership they undertake; (3) conducting in-depth interviews on the head of study program. In the interviews, the atmosphere was informal and natural; (4) use documentation techniques to document all information obtained from informants through internal audit results of data of 2016; (5) identifies and classifies data that are fixed or do not show changes in various situations and conditions.

\section{RESEARCH RESULT AND DISCUSSION}

As a follow-up action of the data obtained through surveys, interviews and data on internal quality audit results and the valid research leadership instruments were used to capture data from respondents. The results of the research were discussed in a row descriptively as follows

\section{Faculty and Postgraduate Program Preparation Implements an IQA system}

The readiness of faculty and postgraduate programs to implement the quality assurance system can be seen from the aspect of ownership of IQA system policy documents, IQA system manuals, IQA system standards and IQA system forms and IQA system management. Based on the research results, the faculty and postgraduate program already have IQA system policy documents, IQA system manuals, IQA system standards and IQA system forms. Meanwhile, in terms of implementation aspect of IQA system, it is indicated by IQA system management indicator that is standard setting, standard implementation, evaluation of standard implementation, controlling, and standard improvement which is called PPEPP one cycle, which is explained as follows.

First, standard setting: Since the issuance of Permendikbud No.49 of 2014 on the Higher Education National Standard (commonly called $S N$-Dikti) promulgated on June 11, 2014, Quality Assurance Agency of UKI took the initiative to study the regulation and subsequently disseminated. The results of the study on standard setting, UKI shall implement the 24 SN-Dikti and have even exceeded $S N$-Dikti by implementing 31 quality standards of UKI. The leaders of FKIP, FS, FH, FE, FK, FISIP and postgraduate programs responded positively to the determination of 31 quality standards in the UKI, thus forming a standard-setting drafting team. After one year of Permendikbud No.49 of 2014 on SN-Dikti was promulgated, there was rejection from various parties by reason of incriminating point such as increasing number of Semester Credits System for master program from 36 credits in to 72 credits. Therefore Permenristekdikti No.44 of 2015 on $S N$ Dikti promulgated December 28, 2015 as a substitute to Permendikbud no.49 year 2014. On this basis then UKI evaluate against 31 standards and adjust.
Second, the implementation of standards: Since established through Decree of Rector. No. UN / 40a / SK.REK / 08.2015 about the implementation of UKI IQA system, so every faculty and postgraduate program must implement 31 quality standard. Based on the results of internal quality audit found that some standards are still difficult to be implemented, including: (1) graduate competency standards for coverage of UKI attitude and values; (2) standard learning process for standard coverage of learning characteristics; (3) the standard of assessment of learning on the scope of learning assessment principles.

Third, evaluate the implementation of standards: At the time of the standard execution process, faculty leaders and postgraduate programs monitor the implementation of standards every month. At the end of the semester the standard implementation is evaluated by the internal quality auditor of the University Quality Assurance Agency. Internal quality audit aims to know the availability of documents in accordance with the standards and to know compliance with standards implementation. The audit team under the Quality Assurance Board sets a 2 day audit schedule and the faculty leader is pleased to present and provide information honestly in the hope of improving academic and non academic quality so that it becomes a culture in the faculty and postgraduate programs. Based on the results of surveys conducted by BPM, it was found that: (1) faculty and postgraduate leaders welcomed the audit and realized how important the audit was. (2) non-compliance with the implementation of established standards, such as: (a) no studies with foreign funds (categorized as KTS); (b) there is no document of academic supervisor (categorized as OB).

Fourth, control of evaluation results: Evaluation results through audit activities by BPM are reported to university leaders. However, in the process of controlling the results of the evaluation, there are obstacles found that the university leadership is very busy with various activities so have not had time to look and review what the findings. In essence, the Rector should immediately follow up the findings by issuing the Rector's Decree so that the faculty and postgraduate leadership will improve every finding. As a solution to these constraints BPM reviewed the findings to make it easier for university leaders to review the findings. The Rector makes a Decision Letter so that the findings will be improved by the faculty and the postgraduate program and the results of standard compliance will be upgraded.

Fifth, the standard increase: The results of the evaluation of the implementation of standards by BPM are as follows: some of the implementation has been fulfilled and some standards that its implementation is not in accordance with the established standards. The findings of OB and KTS must be improved by faculty and postgraduate programs leaders in stages. Standards that have been met must be improved in quality and quantity. Having implemented one cycle for a year, a culture of quality grows in UKI. This can be seen from the mutual agreement between the Quality Assurance Agency and faculty and postgraduate programs leaders in 
order to develop 31 university level standards to 62 quality standards because from the experience when filling in the accreditation form of the undergraduate program consisting of 100 questions has not been covered in 31 standard. This development is done by combining accreditation form and IQA system items. With the development of 31 universitylevel quality standards to 62 quality standards faculty level and postgraduate program so that facilitate the process of filling accreditation program.

TABLE II. 31 Quality Standards of UKI

\begin{tabular}{|c|c|c|c|}
\hline No & Name of Standards & No & Name of Standards \\
\hline 1 & $\begin{array}{l}\text { Graduate competence } \\
\text { standard }\end{array}$ & 17 & $\begin{array}{l}\text { Content Standards } \\
\text { Learning }\end{array}$ \\
\hline 2 & $\begin{array}{l}\text { Learning Process } \\
\text { Standards }\end{array}$ & 18 & $\begin{array}{l}\text { Learning Assessment } \\
\text { Standards }\end{array}$ \\
\hline 3 & $\begin{array}{l}\text { Standards of } \\
\text { Lecturers and } \\
\text { Education Personnel }\end{array}$ & 19 & Infrastructure \\
\hline 4 & $\begin{array}{l}\text { Management of } \\
\text { Learning }\end{array}$ & 20 & $\begin{array}{l}\text { Learning Financing } \\
\text { Standards }\end{array}$ \\
\hline 5 & $\begin{array}{l}\text { Standard of research } \\
\text { results }\end{array}$ & 21 & $\begin{array}{l}\text { Standard content of the } \\
\text { research; }\end{array}$ \\
\hline 6 & $\begin{array}{l}\text { Standard research } \\
\text { process; }\end{array}$ & 22 & $\begin{array}{l}\text { The standard of research } \\
\text { assessment; }\end{array}$ \\
\hline 7 & Standard researcher & 23 & $\begin{array}{l}\text { Standard of research } \\
\text { management }\end{array}$ \\
\hline 8 & $\begin{array}{l}\text { Standard of research } \\
\text { facilities and } \\
\text { infrastructures; }\end{array}$ & 24 & $\begin{array}{l}\text { Funding standards and } \\
\text { research financing }\end{array}$ \\
\hline 9 & $\begin{array}{l}\text { Standard of } \\
\text { community service; }\end{array}$ & 25 & $\begin{array}{l}\text { Standard content of } \\
\text { community service; }\end{array}$ \\
\hline 10 & $\begin{array}{l}\text { Standard process of } \\
\text { community service }\end{array}$ & 26 & $\begin{array}{l}\text { Standard of community } \\
\text { service evaluation; }\end{array}$ \\
\hline 11 & $\begin{array}{l}\text { Standards of } \\
\text { implementing } \\
\text { community service; }\end{array}$ & 27 & $\begin{array}{l}\text { Standard of facilities and } \\
\text { infrastructure of } \\
\text { community service; }\end{array}$ \\
\hline 12 & $\begin{array}{l}\text { Standard of } \\
\text { community service } \\
\text { management; }\end{array}$ & 28 & $\begin{array}{l}\text { Standards for funding and } \\
\text { financing community } \\
\text { service }\end{array}$ \\
\hline 13 & Standard identity & 29 & Welfare standards \\
\hline 14 & $\begin{array}{l}\text { Standards of } \\
\text { information systems }\end{array}$ & 30 & $\begin{array}{l}\text { Student and alumni } \\
\text { standards }\end{array}$ \\
\hline 15 & $\begin{array}{l}\text { Standard of } \\
\text { cooperation }\end{array}$ & 31 & $\begin{array}{l}\text { PR, and marketing } \\
\text { standards }\end{array}$ \\
\hline 16 & $\begin{array}{l}\text { Standard academic } \\
\text { atmosphere }\end{array}$ & & \\
\hline
\end{tabular}

TABLE III. 62 Quality Standards of Faculty and Postgraduate Program

\begin{tabular}{|l|l|l|l|}
\hline No & Name of Standards & No & Name of Standards \\
\hline 1 & $\begin{array}{l}\text { Graduate competence } \\
\text { standard }\end{array}$ & 32 & $\begin{array}{l}\text { Content Standards } \\
\text { Learning }\end{array}$ \\
\hline
\end{tabular}

TABLE III, Cont.

\begin{tabular}{|c|c|c|c|}
\hline 2 & $\begin{array}{l}\text { Learning Process } \\
\text { Standards }\end{array}$ & 33 & $\begin{array}{l}\text { Learning Assessment } \\
\text { Standards }\end{array}$ \\
\hline 3 & $\begin{array}{l}\text { Standards of } \\
\text { Lecturers and } \\
\text { Education Personnel }\end{array}$ & 34 & Infrastructure \\
\hline 4 & $\begin{array}{l}\text { Management of } \\
\text { Learning }\end{array}$ & 35 & $\begin{array}{l}\text { Learning Financing } \\
\text { Standards }\end{array}$ \\
\hline 5 & $\begin{array}{l}\text { Standard of research } \\
\text { results }\end{array}$ & 36 & $\begin{array}{l}\text { Standard content of } \\
\text { research }\end{array}$ \\
\hline 6 & $\begin{array}{l}\text { Standard research } \\
\text { process; }\end{array}$ & 37 & $\begin{array}{l}\text { The standard of research } \\
\text { assessment; }\end{array}$ \\
\hline 7 & Standard Researcher & 38 & $\begin{array}{l}\text { Standard of research } \\
\text { management }\end{array}$ \\
\hline 8 & $\begin{array}{l}\text { Standard of research } \\
\text { facilities and } \\
\text { infrastructures; }\end{array}$ & 39 & $\begin{array}{l}\text { Funding standards and } \\
\text { research financing }\end{array}$ \\
\hline 9 & $\begin{array}{l}\text { Standard PKM } \\
\text { results }\end{array}$ & 40 & Content standard of PKM \\
\hline 10 & $\begin{array}{l}\text { Standard PKM } \\
\text { process }\end{array}$ & 41 & PKM assessment standard \\
\hline 11 & $\begin{array}{l}\text { Implementing } \\
\text { standards of PKM }\end{array}$ & 41 & $\begin{array}{l}\text { PKM facilities and } \\
\text { infrastructure standard }\end{array}$ \\
\hline 12 & $\begin{array}{l}\text { PKM management } \\
\text { standards }\end{array}$ & 43 & $\begin{array}{l}\text { PKM funding and } \\
\text { financing standards }\end{array}$ \\
\hline 13 & Standard Vision & 44 & Standard Mission \\
\hline 14 & Standard Goals & 45 & $\begin{array}{l}\text { Standard Achievement } \\
\text { Strategy }\end{array}$ \\
\hline 15 & $\begin{array}{l}\text { Socialization } \\
\text { Standards }\end{array}$ & 46 & Standard Tata Pamong \\
\hline 16 & Leadership Standards & 47 & Management Standards \\
\hline 17 & $\begin{array}{l}\text { Admissions Standard } \\
\text { New Students }\end{array}$ & 48 & $\begin{array}{l}\text { Standard of Student } \\
\text { Organization }\end{array}$ \\
\hline 18 & $\begin{array}{l}\text { Standards of Student } \\
\text { Activities }\end{array}$ & 49 & $\begin{array}{l}\text { Standard of Student } \\
\text { Services }\end{array}$ \\
\hline 19 & $\begin{array}{l}\text { Standard of Alumni } \\
\text { Association }\end{array}$ & 50 & $\begin{array}{l}\text { Standard of Graduate } \\
\text { Tracking Standards }\end{array}$ \\
\hline 20 & $\begin{array}{l}\text { Standard Alumni } \\
\text { User Tracking } \\
\text { Standards }\end{array}$ & 51 & Standard Bimb. Academic \\
\hline 21 & $\begin{array}{l}\text { Standard of } \\
\text { Internship Guidance / } \\
\text { PPL }\end{array}$ & 52 & Standard Bimb. Thesis \\
\hline 22 & $\begin{array}{l}\text { Standards of } \\
\text { Scientific Autonomy }\end{array}$ & 53 & $\begin{array}{l}\text { Standards of Academic } \\
\text { Freedom }\end{array}$ \\
\hline 23 & $\begin{array}{l}\text { Standard of } \\
\text { Academic Mimbar }\end{array}$ & 54 & $\begin{array}{l}\text { Lecturer's Scientific } \\
\text { Standards }\end{array}$ \\
\hline 24 & $\begin{array}{l}\text { Standard of } \\
\text { Procurement of } \\
\text { Library Material }\end{array}$ & 55 & $\begin{array}{l}\text { Academic Information } \\
\text { Standards }\end{array}$ \\
\hline 25 & $\begin{array}{l}\text { Financial } \\
\text { Information } \\
\text { Standards }\end{array}$ & 56 & $\begin{array}{l}\text { Standard of Personnel } \\
\text { Information }\end{array}$ \\
\hline
\end{tabular}


TABLE III, Cont.

\begin{tabular}{|c|l|l|l|}
\hline 26 & $\begin{array}{l}\text { Library Information } \\
\text { Standards }\end{array}$ & 57 & $\begin{array}{l}\text { Information Standards of } \\
\text { Graduates and Graduate } \\
\text { Users }\end{array}$ \\
\hline 27 & $\begin{array}{l}\text { Inventory } \\
\text { Information } \\
\text { Standards }\end{array}$ & 58 & $\begin{array}{l}\text { Standards of Education } \\
\text { and Teaching Cooperation }\end{array}$ \\
\hline 28 & $\begin{array}{l}\text { Standard of Research } \\
\text { Cooperation }\end{array}$ & 59 & $\begin{array}{l}\text { PKM Cooperation } \\
\text { Standards }\end{array}$ \\
\hline 29 & $\begin{array}{l}\text { Standards of Library } \\
\text { Cooperation }\end{array}$ & 60 & Standard PR \\
\hline 30 & Welfare Standards & 61 & Marketing Standards \\
\hline 31 & $\begin{array}{l}\text { UKI Identity } \\
\text { Standard }\end{array}$ & 62 & General Service standards \\
\hline
\end{tabular}

The implementation of one cycle PPEPP (31 standards) is difficult to understand by the faculty and the postgraduate program leaders and indicated by indicators; they say that quality assurance activities are the main task of the quality assurance agency. It is unfortunate that the leader should be the guarantor of quality, but not act as a quality assurance. BPM nevertheless socialize IQA system to the leadership periodically with the aim that the leaders have an understanding that the leader who becomes the guarantor of quality. Rector as university-level quality guarantor, dean as guarantor of faculty level quality, and director to postgraduate quality program.

\section{Leadership Style of Christian University of Indonesia}

The results of the data taken through questionnaire which had been distributed to 168 respondents can be seen in the table below. The leadership styles reviewed in this research are 1) leadership style patterned on the importance of task implementation, 2) leadership style patterned on the implementation of cooperative relations, 3) leadership style patterned on the interests of the results achieved, as can be seen in the table in Below this.

TABLE IV. Leadership Style

\begin{tabular}{|l|c|c|c|}
\hline Score & $\begin{array}{c}\text { Task } \\
\text { Implementation }\end{array}$ & $\begin{array}{c}\text { The } \\
\text { Implementation } \\
\text { of Cooperative } \\
\text { Relations } \\
\text { Interests } \\
\text { of the } \\
\text { Results } \\
\text { Achieved }\end{array}$ \\
\hline $\begin{array}{l}\text { Total } \\
\text { Items }\end{array}$ & 9 & 11 & 10 \\
\hline Total & 4820 & 6774 & 6043 \\
\hline Mean & 602.50 & 615.82 & 604.30 \\
\hline$\%$ & $27.32 \%$ & $38.40 \%$ & $34.26 \%$ \\
\hline
\end{tabular}

From the table it can be seen that the average patterned leadership style on the implementation of the task is 602.50 , while the average style of leadership patterned on the implementation of working relationships that is 615.82, and the average leadership style patterned on the interests of the results achieved is 604.30 . From these data, it can be concluded that the leadership style that existed in Christian University of Indonesia is a patterned leadership style in the implementation of working relationship (38.40\%) and leadership style patterned on the importance of the result achieved $(34.26 \%)$. It can be said that in the leadership of each leader, they are merely a symbol. Leadership is exercised by giving full freedom to the person who is led in making decisions and performing activities according to the will and interests of each individual, as well as small groups. Leaders only function themselves as advisers. In addition, leaders place their subordinates as the main and most important factor in any group/organization. They see and place the people he leads as subjects who have personality with various aspects, such as himself. Willingness, will, ability, thoughts, opinions, creativity, different initiatives and appreciated are equitably channeled. And always try to take advantage of every person he leads.

\section{Leadership Style in Implementation of IQA system}

Judging from the observation about the leadership style implemented in UKI is a patterned leadership style in the implementation of work relationship is the most dominating style of leadership compared with other leadership styles. This can be seen from the questionnaire data that has been analyzed that is about $38.40 \%$ of faculty, study program and postgraduate leader in their leadership, implemented the leadership style. After that followed by a leadership style patterned on the interests of the results achieved that is about $34.26 \%$ faculty, study program and postgraduate leader in their leadership, implemented the style of leadership.

Meanwhile, if we look at the results of IQA system implementation in UKI that the faculty and postgraduate program leaders have IQA system policy documents, IQA system Manual, 31 quality standards, IQA system form but have not fully understood IQA system. The leaders objected to developing 62 standards, some of which said enough 24 mandatory SN-Dikti. In addition, the founder also keeps the document has not studied and said the IQA system makes the leadership duties more and more severe. In addition, some standards are difficult to implement, such as graduate competency standards for the scope of attitudes and values and values of UKI, learning process standards for standardized coverage of learning characteristics, learning assessment standards in the scope of learning assessment principles are difficult to measure operationally. Then there are some standards that are difficult to implement such as graduate competency standards for coverage of attitudes and values and values of UKI, learning process standards for standardized coverage of learning characteristics, learning 
assessment standards on the scope of learning assessment principles are difficult to measure operationally. Moreover the control of the evaluation results are still low because the University's leaders are very busy with various activities so have not had time to look and review what the findings. Finally, standard upgrades can not be made quickly by faculty leaders because university leaders are considered to be less serious and have not seen their commitment to real quality improvement.

From both of the above explanations, it can be concluded that the two leadership styles are still less appropriately applied to the implementation of IQA system, this can be proven by the application of the two leadership styles, the level of IQA system implementation still experiencing many deficiencies that there are still many constraints Occurs during the IQA system implementation as described above. This is shown in the accreditation results of study program in UKI are as follows: seven (22\%) study programs with C accreditation, twenty one $(66 \%)$ study programs with B accreditation and three (10\%) study programs with A accreditation from thirty one existing study programs.

Furthermore, when viewed from a patterned leadership style on the execution of tasks, it can be seen that about $27.32 \%$ of faculty, study program and postgraduate leader in their leadership, implemented the leadership style. This means that this leadership style is the least leadership style used by faculty, study program and postgraduate leaders in UKI. Yet if return to the theory, then this leadership style is a leadership style that puts power in the hands of one person. The leader acts as sole ruler, and the position and duties of the subordinate solely as the executor of the decisions, orders, and even the will of the leader, if this can be implemented by leaders in UKI, of course, will improve the implementation of the ongoing IQA system.

Thus it can be concluded that the proper leadership style in implementing IQA system is leadership style which patterned on the implementation of tasks. In terms of IQA system; Namely from the aspect of ownership of IQA system policy documents, IQA system Manuals, IQA system Standards and IQA system form and IQA system management, and from the aspect of IQA system implementation that is standard setting, standard implementation, evaluation of standard implementation, controlling, and improvement of standard. IQA system demands the implementation of leadership style leadership that is patterned on the implementation of the task for IQA system can be done well.

\section{CONCLUSION}

IQA system has been implemented in UKI, it can be seen from aspect of ownership of IQA system document namely UKI has had the IQA system policy, IQA system manual, IQA system standard, IQA system form. If it is seen from aspect of IQA system implementation which is indicated by the IQA system management indicator namely UKI has had the standard setting, implementation standard, evaluation on standard implementation, control and standard improvement. It can be said that UKI has set 31 quality standard of IQA system. The study program and the postgraduate program must implement the 31 quality standard which has been set, although there are still some standards which are still difficult to be implemented and the evaluation is still low. The right leadership style which supports the implementation of IQA system in UKI is leadership style patterned on the implementation of the task.

\section{ACKNOWLEDGMENT}

Through this article, the authors would like to thank the leaders at the Indonesian Christian University who have given their time and willingness to be the respondents of this research, as well as to thank the Indonesian Christian University for funding the research. It is our hope that this research can be useful for the progress of the Christian University of Indonesia.

\section{REFERENCES}

[1] Fairlholm, M. R. Leadership and Organizational Strategy. The Innovational Journal: The Public Sectore Innovation Journal, Vol. 14 No. 1. 2009.

[2] Gibson, J. L., John M. I, James H. D, Konopaske R. J. Human Organizations: Behavior, Structure, Proces, Fourteenth Edition. New York: McGraw-Hill, 2009.

[3] Roberts. C. Building Social Capital through Leadership Development. Journal of Leadership Education. Vol. 12 No. 1. pp. 54-72. 2013

[4] Priest, K. L. dkk. Appreciative Inquiry: A Tool for Organizational, Programmatic, and Project-Focused Change. Journal of Leadership Education. Vol. 12 No. 1. pp. 18-32. 2013.

[5] Yukl, G. Leadership in Organization, Seventh Edition New York: Pearson Education Inc. 2010.

[6] Newstorm, J. W. and Keith, D. Organizational Behavior, Human Behavior at Work, $11^{\text {th }}$ Edition. Boston: McGraw-Hill, 2002.

[7] Massey, J. Sulak, T, dan Sriram, R. Influence of Theory and Practice in the Development of Servant Leadership in Studies. Journal of Leadership Education. Vol. 12 No. 1. pp. 86-90. 2013

[8] Wahyudi. Kepemimpinan Kepala Sekolah dalam Organisasi Pemebelajaaran (LearningOrganization). Bandung: Alfabeta.

[9] Chuang, S. F. Essential Skills for Leadership Effectiveness in Diverse Workplace Development. Online Journal for Workplace Education and Development. Vol. 6. No. 1. pp. 1 - 24. 2013.

[10] Timothy, O. C. Andy, O. T. Victoria, A. O. dan Idowu, N. A. Effects of Leadership Style on Organization Performance: A Survey of Selected Small Scale Enterprises in Ikosi-Ketu Council Development Area of Lagos State. Nigeria. Australian Journal of Business and Management Research. Vol. 1. No. 7. pp. 100-111. 2011.

[11] Silman, F. Gokcekus, H. dan Isman, A. A Study on Quality Assurance Activities in Higher Education in North Cyprus. International Online Journal of Education Sciences. Vol. 4 No. 1. pp. 31-38. 2012. 
[12] Hamdatu, M. A. Siddiek, A. G dan Olyan, F. R. Aplication of Quality Assurance \& Acreditation in the Institutes of Higher Education in the Arab World (Descriptive \& Analytical Survey). American International Journal of Contemporary Research. Vol. 3. No. 4. pp. 104-116. 2013.

[13] Hamad, M, Shumos, Hammadi, T. Quality assurance evaluation for higher education institutions using statistical models. International Journal of Database Management Systems (IJDMS). Vol. 3. No. 3. Pp. 88-98. 2011.

[14] Hendel, D. and Lewish, D.R. Quality assurance of higher education in transition countries: Accreditation - accountability and Assessment. Tettiary Education and Management Journal. Vol. 11. Pp. 239 - 258. DOI 10.1007/s11233-005-5111. 2005.

[15] Ryan, T. Quality assurance in higher education: A Review of Literature. High. Learn. Res. Common. Vol. 5. No. 4. pp. 1-12. 2015. 